DOI 10.18551/rjoas.2019-04.16

\title{
THE EFFECT OF SERVICE QUALITY ON CUSTOMER SATISFACTION AT PT MULTI RENTALINDO: A CASE STUDY OF EMPLOYEES IN KAWAN LAMA WEST JAKARTA
}

\author{
Butarbutar Novita, Syah Tantri Yanuar Rahmat, Anindita Rina \\ Faculty of Economics and Business, University of Esa Unggul, Indonesia \\ *E-mail: tantri.yanuar@esaunggul.ac.id
}

\begin{abstract}
Owning a car is certainly the desire of everyone, for those who have not been able to buy a car or do not want to be bothered with maintenance and other costs, or maybe just need a car at certain times. So, alternative car rental is one of the best solutions. Using a rental car / car rental at this time is very easy and quite affordable; this is because the growth of service providers also grows very rapidly. Transportation is known as one of the links of goods and passenger distribution networks that have developed very dynamically and play a role in supporting political, economic, socio-cultural and defense security development. The success of the transportation sector can be seen from its ability to support and encourage the improvement of the national, regional, local, and political stability. This study aims to analyze service quality, customer satisfaction and customer loyalty at PT. Multi Rentalindo. The data analysis method used is Structural Equation Modeling by using 132 respondents of employees of the company PT. Kawan Lama as a research sample in November 2018. The results showed that service quality has a positive effect on customer satisfaction and customer loyalty, so customer satisfaction can increase customer loyalty.
\end{abstract}

\section{KEY WORDS}

Service, reliability, responsiveness, guarantee, customer satisfaction, customer loyalty.

The growth of the national automotive industry greatly influenced the rapid car rental business in Indonesia. The Association of Indonesian Vehicle Rental Companies (Asperkindo) estimates that in 2019 there will be a significant surge in car rental in the national market. This situation, if supported by a relatively stable economic condition and conducive political and national security climate, car rental business opportunities remain promising and can certainly continue to grow until the next few years (http://www.ikpi.or.id).

According to Pongki Pamungkas, the chairman of Asperkindo based on the article quoted on Kapanlagi.com (January, 2011), "Competition in the car rental business is increasingly unhealthy and there is a tendency to slam rates, especially for small business players but natural selection will determine. If the vehicle rental company slams rates, it will certainly affect maintenance, delivery service to consumers and so on. Asperkindo always reminds association members to calculate the correct cost structure. "The Muslim Entrepreneur Magazine (January, 2011) in his article mentions that the transportation business is actually a service business.

The company must be able to bind consumers with products in the form of attractive and attractive services, so that consumers remain loyal to use the service provider services, of course with the right and effective strategy. In Indonesia there are not many transportation service providers that really provide good service in the form of service, convenience, and security to their customers. PT. Multi Rentalindo as one of the specialized vehicle rental providers (in Kawan Lama Group) both long-term leasing (leasing) and short-term (rental) as much as possible to go public serving companies outside the Kawan Lama Group.

\section{LITERATURE REVIEW}

Service quality is someone's actions to other parties through the presentation of products or services according to the tastes, expectations and needs of consumers. 
Companies can provide services that are in accordance with the wishes expected by consumers, the quality of service of the company is good. Good service will give encouragement to consumers to make repeat purchases at the company. (Gronroos, 1984) proposed the concept of perceived customer service quality for the first time, and he believed that service quality was a comparison between expected customers and perceived service, including technical parts (service results) and functional parts (service processes).

According to Sulastiyono (2008: 35 ) the assessment of the quality of service is determined by guests as users of these services. In other words, service quality is the best value of the services provided to customers. Therefore, service quality can be created by first identifying guest expectations about the services needed and desired, then adjusted to the services needed and desired, then adjusted to the services that will be provided by the hotel. Customer satisfaction is a real impact that directly arises when service quality can meet expectations and customer's specific requirements. This is justified by (Tjiptono, 2006) that quality is closely related to customer satisfaction.

Goetsh and Davis cited by Tjiptono (2001: 51) define quality as follows: "Quality is a dynamic condition that relates to products, services, people, nature and environment that meet or exceed expectations". The definition of quality has the following elements: 1) Quality includes efforts to meet needs. 2) Quality includes products, services, people and the environment. 3) Quality is an ever-changing condition. From the definition above it can be concluded that service quality is the key to achieving success. Whether or not the quality of service for goods or services depends on the ability of producers to consistently meet consumer expectations. Consumers who feel satisfied indirectly create loyalty, and encourage recommendations from mouth to mouth, can even improve the company's image in the eyes of consumers. Therefore service quality must be the main focus of the company's attention. The essence of the concept of service quality is to show all forms of actualization of service activities that satisfy those who receive services in accordance with responsiveness (responsiveness), foster assurance (assurance), show physical evidence (tangible) that can be seen, according to empathy (empathy) of those who provide reliabilitybased services that carry out the duties of service that are consequently given to satisfy those who receive service.

Reliability services are very important in the work dynamics of an organization. Reliability is a form of characteristic or characteristic of employees who have high work performance. Reliability in service delivery can be seen from the reliability of providing services in accordance with the level of knowledge, reliability in mastering the applied work field, reliability in mastering the work field according to work experience. demonstrated and reliability using work technology. For the Reliability dimension, it consists of indicators: a. The ability of officers to deliver services clearly b. Expertise in providing services c. Timeliness of service and discipline of employees d. Responsibilities of officers in providing services. Sunyoto (2004: 16) the reliability of an individual organization in providing services is needed to deal with the rolling dynamics of work demands high quality service according to individual employee reliability. Every service requires a reliable form of service, meaning that in providing services, every employee is expected to have the ability in high knowledge, expertise, independence, mastery and work professionalism, so that the work activities carried out produce satisfying forms of service, without any complaints and excessive impressions for services received by the community (Parasuraman, Zeithaml, \& Berry, 1998).

The company's ability to deliver promised services accurately since the first time, for example a company might choose a consultant solely based on reputation. If the consultant is able to provide what the client wants, the client will be satisfied and pay a consulting fee. However, if the consultant embodies what the client expects, the consultation fee will not be paid in full (Tjiptono, 2012: 174).The demands of the reliability of employees in providing services that are fast, precise, easy and smooth become the assessment requirements for the people served in showing the actualization of the work of employees in understanding the scope and description of work that is the concern and focus of each employee in providing services. The core service of reliability is that every employee has a reliable ability, knows about the ins and outs of work procedures, working mechanisms, corrects various 
deficiencies or irregularities that are not in accordance with work procedures and is able to show, direct and give correct direction to any form of service that has not been understood by the community, so that it has a positive impact on the service, namely employees understand, master, are reliable, independent and professional in their work description (Parasuraman, Zeithaml, \& Berry, 1998).

Responsibility is a policy to help and provide services that are fast (responsive) and appropriate to customers, with the delivery of clear information. Let consumers wait for negative perceptions in service quality. For the Responsiveness dimension, it consists of indicators: a. Respond to every customer/applicant who wants to get service b. Accuracy and timeliness of officers in serving customers c. The clerk helps customers obtain information and respond to customer complaints. According to (Tjiptono, 2012) regarding the willingness and ability of service providers to help customers and respond to their requests immediately. Every employee in providing forms of service, prioritizes aspects of service that greatly affect the behavior of people who receive services, so that the responsiveness of employees is needed to serve the community in accordance with the level of absorption, understanding, incompatibility of various forms of service that he does not know. This requires a wise explanation, detailed, fostering, directing and persuading to address all forms of procedures and working mechanisms that apply in an organization, so that the form of service gets a positive respons (Parasuraman, 2001).

Assurance (guarantee) is one dimension that becomes a measure of service quality. That is the ability of employees to foster trust in the customers in their organization. Consists of several components including competence (proficiency), courtesy (politeness), credibility (credibility), security (security), and communication (communication). The form of certainty of a service is largely determined by guarantees from employees who provide services, so that people who receive services are satisfied and believe that all forms of service matters carried out are completed and completed in accordance with the speed, accuracy, ease and quality of services provided ( Parasuraman, 2001: 69) For the dimension of Assurance (Guarantee), it consists of indicators: a. Guarantee the ease of service procedures b. Guaranteed ease of service requirements c. Guaranteed cost certainty in service d. Guaranteed certainty of service completion time. The other forms of collateral are guarantees for employees who have good personality behavior in providing services, of course there will be different employees who have characters or characters that are less good and who are not good at providing services (Margaretha, 2003: 201).

Satisfaction is the level of one's feelings (customers) after comparing between performance or perceived results (services received and felt) with what he expected. Service is expected to make customers satisfied by giving customers what they really need and want, not giving what we think they need. Churchill \& Surprenant in (Tjiptono, 2006: 349) formulates customer satisfaction as a result of purchases and usage obtained from a comparison between reward and purchase costs with the anticipated consequences. Whereas Westbrook \& Reilly in Tjiptono (2006: 349) argue that customer satisfaction is an emotional response to experiences related to certain products or services purchased, retail outlets, or even behavioral patterns (such as shopping behavior and buying behavior), as well as markets whole. Oliver (1980) defined customer satisfaction as a comparison between expectations and experiences before and after buying, it is a DISCON-hope for technical theory. He believes that customer satisfaction is a relative concept. If the product or service exceeds customer expectations, the level of customer satisfaction is high; if not, it's low.

Dick and Basu (1994) believe that customer loyalty is a long-term commitment that customers want to buy products consistently. Oliver (1999) shows that customer loyalty is a commitment to re-buy and re-patronize brand products and services consistently in the future. Fornell (1992) thinks that customer loyalty must be measured in two aspects: whether customers want to buy products or services consistently and whether satisfied customers are willing to pay more for products or services. Burton et al. (2003) are consistent and whether satisfied customers are willing to pay more for products or services. Burton et al. (2003) are consistent and whether satisfied customers are willing to pay more for products or services. Burton et al. (2003) believe that customer loyalty is determined by whether the customer's 
experience is satisfied. the more experience customers are satisfied, the more they are willing to buy products or services again.

Indicators of customer loyalty according to Kotler \& Keller $(2006 ; 57)$ are Repeat Purchases (loyalty to product purchases); Retention (Resistance to negative influences about the company); referrals (referring in total to the company's existence).

Furthermore Griffin $(2003 ; 223)$ suggests the benefits that the company will get if it has loyal customers, among others:

- Reducing the cost of marketing (because it costs to attract new customers is more expensive);

- Reducing transaction costs (such as contract negotiation fees, order processing, etc);

- Reducing customer turnover costs (due to fewer customer changes);

- Increase cross sales which will increase the company's market share;

- A more positive word of mouth assuming that loyal customers also mean those who are satisfied;

- Reducing failure costs (such as replacement costs, etc).

Zeithaml $(2000 ; 211)$ explains that loyal customers will usually do the following: 1 . Will trough word of mouth new customers with similar relationship potential. 2 . Less likely to be pulled away by competitors. 3. Buy more product / service from the company over time. Understanding this loyalty until now, none of the experts and books are considered the most perfect, especially in providing the right terminology. This is also recognized by Egan (2001; 312). Javalgi and Mobers in Egan $(2001$; 313) provide two definitions of loyalty in two terms: 1. In Behavioral terminology Usually based on purchases and measured by the frequency of such purchases and brand switching. 2. In Attitudinal terminology Incorporating consumer preferences and dispositions towards brands to determine levels of loyalty.

\section{HYPOTHESIS DEVELOPMENT}

Wang \& Shieh (2006) state that overall reliability has a very positive impact on customer satisfaction. A similar statement was also conveyed by Raza, et al (2012), that reliability has an important and positive relationship with customer satisfaction and makes consumers return to use the service. Akhtar, et al (2011) states that there is a positive and significant relationship between service quality and customer satisfaction such as compliance obligations, guarantees, and reliability.

H1. Reliability has a positive effect on customer satisfaction.

According to Parasuraman in Tjiptono and Chandra (2005: 134) which states that "responsiveness relates to the ability of employees to help customers and respond to their requests, and inform when services will be provided and then provide services quickly, if employees respond quickly to serving customers then the company will get sympathy from the customer itself ". Studies have found that response is not only an important component of the service quality model but also has a positive effect on customer satisfaction (Al-Azzam 2015). If employees are very responsive to customers it will lead to a higher level of customer satisfaction (Al-Azzam 2015). The level of response is very dependent on employee attitudes and behavior. As such, it is important for companies to provide the orientation needed for their employees on a regular customer relationship. As a result, this will lead to higher problems (Khan \& Fasih 2014). Factors such as employee knowledge and politeness also help in expanding trust (Parasuraman \& Zeithaml, 1988). Previous research shows that positive trust affects customer satisfaction. customer trust in employees leads to higher levels of satisfaction and positively influences purchase intentions (Khan \& Fasih 2014).

H2. Responsiveness has a positive effect on customer satisfaction.

Guarantee and Customer Satisfaction refers to customer trust and confidence in the company to provide the best service to them (Arsanam \& Yousapronpaiboon 2014).

H3. Guarantees have a positive effect on customer satisfaction.

Reliability is the ability to carry out promised services that are trusted and accurate (Parasuraman, Zeithaml, \& Berry, 1985). Research findings indicate that reliability has a 
positive relationship with customer loyalty (Kheng et al., 2010).

H4. Reliability has a positive effect on customer loyalty.

Responsiveness is the willingness to help customers, and provide fast service (Parasuraman et al., 2002). The relationship between response and customer loyalty was found to be insignificant (Kheng et al., 2010). These results conflict with findings that reveal a positive and significant relationship between response and loyal customers (Glaveli, Petridou, Liassides, Spathis 2006; AUKA et al., 2013).

H5. Responsiveness has a positive effect on customer loyalty.

Guarantees represent the knowledge and politeness of employees and their ability to inspire trust and confidence (Parasuraman et al., 2002). Consistent with the study by Ndubisi (2006), other researchers also found a significant relationship between guarantee and customer loyalty (Lymperopoulos, Chaniotakis \& Soureli, 2006; Kheng et al., 2010; AUKA et al, 2013).

H6. Guarantees have a positive effect on customer loyalty.

Consumers will be loyal or loyal to a brand if consumers get satisfaction from the brand. To increase customer satisfaction, the company needs to regulate the structure marketing strategy so that consumers are interested in the products offered. If the product gives satisfaction to consumers then consumers will remain loyal to use the brand and try to limit the purchase of other products. This is in accordance with research conducted by Maylina (2003), where satisfaction has a significant positive effect on brand loyalty to consumers. Every business actor certainly wants a condition of relationships that are successes, where the level of satisfaction and customer loyalty is high. Because at this position, the company will get many benefits as well as stimulating customers to tell positive things to other customers (word of mouth communication), can also reduce marketing costs, attract new customers, respond to competitors' threats, and obtain cumulative value for sustainable business (Aaker, 1995, in Hasan, 2009: 79).

Fornell (1992) thinks that customer loyalty must be measured in two aspects: whether the customer wants to buy the product or service consistently and whether satisfied customers are willing to pay more for the product or service. Burton et al. (2003) believe that customer loyalty is determined by whether the customer's experience is satisfied. The experience of more satisfied customers, the more they are willing to buy products or services again.

H7. Customer satisfaction has a positive effect on customer loyalty

\section{METHODS OF RESEARCH}

The study was conducted in November 2018 with the research method using quantitative descriptive research methods, according to Sugiyono (2013: 23) quantitative methods because research data in the form of numbers and analysis using statistics. Quantitative methods are used if the problem is a deviation between what is supposed to be and what happens, between rules and implementation, between theory and practice, between plans and implementation. The method of data analysis in this study uses Structural Equation Modeling (SEM). The sampling process is carried out using the entire population and the number meets the requirements for the SEM method, which Ferdinand (2002) states that the number of representative samples to use SEM analysis techniques is 100-200. The object of this research is PT head office employees. Kawan Lama, located in West Jakarta with a total population of 132 respondents. The aspects studied were service quality, customer satisfaction and customer loyalty. The data measurement method uses a Likert scale with one to five scale intervals.

This study uses 1 independent variable, namely customer loyalty and two dependent variables, namely service quality (reliability, responsiveness, assurance). Measurement of service quality variables proposed by Ratminto and Atik (2007, p. 179), based on several literature reviews, can be concluded that to measure service quality, namely: Size-oriented results that include: a. Effectiveness that is the achievement of predetermined goals, both in the form of targets, long-term goals and organizational mission. According to Kotler quoted 
by Tjiptono (1996: 148) there are four methods for measuring customer satisfaction, namely as follows. 1) Measurement of customer satisfaction through this method can be done in various ways, including the following. a.Directly reported satisfaction, that is, measurements are made directly through questions, but achieving this goal must also refer to the organization's vision. b. Productivity is a measure that indicates the government's ability to produce output needed by the community. c. Efficiency is an inverse comparison between output and input. Ideally the government should be able to organize a certain type of service with as little input (cost and time) as possible. Thus, the government's performance will be even higher if the stated objectives can be achieved in the shortest possible time and at the cheapest cost. d. Satisfaction, meaning how far the government can meet the needs of employees and the community. e. Equitable justice, meaning that the scope or range of activities and services provided by the government must be as wide as possible with equitable distribution and treated fairly. 2) Process- oriented size. a. Responsiveness, namely the ability of the government to recognize community needs, set the agenda and priority of services, and develop service programs in accordance with the needs and aspirations of the community. This responsiveness measures the government's responsiveness to customer expectations, desires and aspirations and demands. b. Responsibility is a measure that shows how much the level of suitability between the administration of the government and the laws or regulations and procedures has been set. c. Accountability is a measure that shows how much the level of conformity between the administration of the government and external measures that exist in the community and owned by stakeholders, such as values and norms that develop in the community. $d$. Adaptation is a measure that shows the responsiveness of an organization to the demands of changes that occur in its environment. e. Survival means how far the government or service program can demonstrate the ability to continue to grow and survive in competing with other regions or programs. f. Openness or transparency is a procedure / procedure, administration of government and other matters relating to the public service process must be informed openly so that it is easily known and understood by the public, both requested and unsolicited. g. Empathy is the treatment or attention of the government or service providers to actual issues that are developing in the community.

Customer satisfaction indicators Tjiptono (2005), "Customer movements or campaigns are also based on the idea that satisfied customers tend to be more loyal, not easily tempted to switch to suppliers that offer cheaper prices and potentially disseminate their profit experience to others". According to Kotler (2003), the characteristics of satisfied customers are as follows: a. Become more loyal or become a loyal customer b. Buy more if the company introduces new products or products and perfects existing products c. Give favorable comments about the company's products $d$. Less attention to products, advertising e. competitors, less sensitive to prices f. Giving ideas or ideas to the company g. Requires a service fee that is smaller than the cost of a new customer, because the transaction becomes routine.

According to Griffin (2005), "Customer loyalty indicators are a reliable measure to predict sales growth as well as customer loyalty can be defined based on consistent consumer buying behavior". 1) Customers make regular repeat purchases 2) Buy between product lines or services (purchase across product and service lines). 3) Referring to other people (Refers other). 4) Demonstrating immunity to attraction from competitors (demonstrating immunity to the full of the competition).

Furthermore, from the dimensions of the measurement displayed in the form of a questionnaire, then tested the validity and reliability test. Validity test is carried out with Confirmatory Factor Analysis by looking at the value of Kaiser-Meyer-Olkin Measure of Sampling (KMO) and Measures of Sampling Adequacy (MSA). In this test the value obtained must be greater than 0.5 , which means that the analysis of factors is appropriate or suitable for use, and can be further processed (Malhotra, 2004). The scale of service quality consists of 20 questions and 5 of them are invalid so there are 15 questions left, the customer satisfaction scale consists of 10 questions and 2 of them are invalid so there are 8 questions left, the customer loyalty scale consists of 10 questions and all are valid. The reliability test of 
Cronbach Alpha value is greater or equal to 0.7 , which means reliable, that is to say service quality, customer satisfaction and customer loyalty can be said to be trusted as a tool for collecting data in research. The next stage, the data is processed using the SEM analysis method.

\section{RESULTS AND DISCUSSION}

The focus of this study is service quality (Reliability, Responsiveness and Assurance), on customer satisfaction and customer loyalty where the results of reliability and assurance show that the hypothesis data supports hypotheses or hypotheses accepted, as SEM testing has been done, and can be seen in Figure 1 the following:

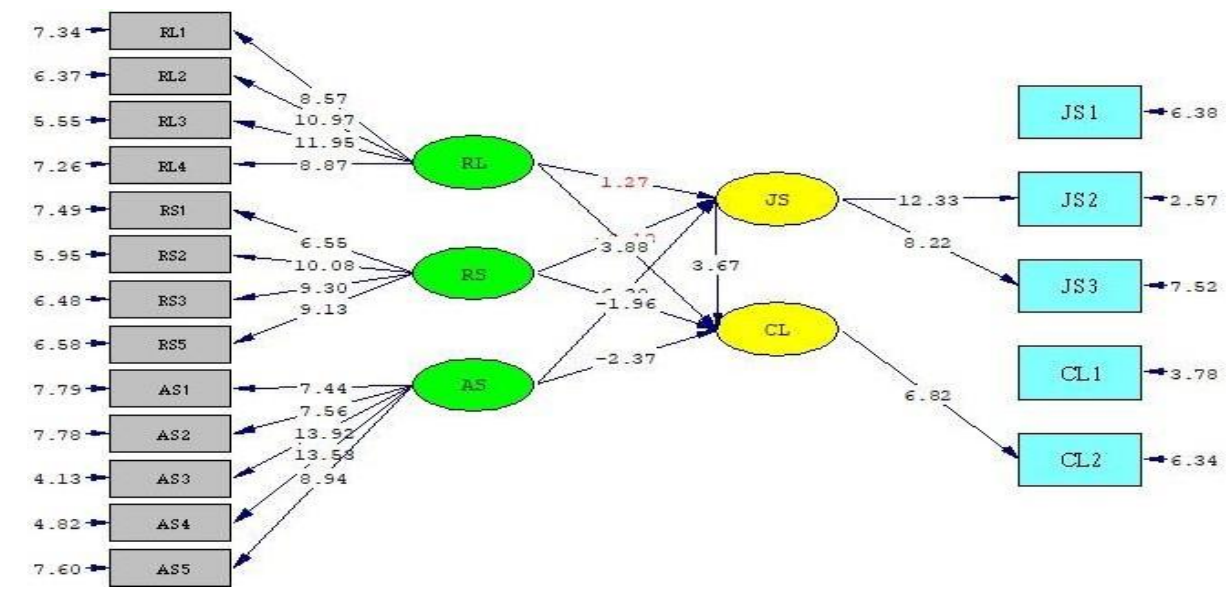

\begin{tabular}{|c|l|c|c|}
\hline Hypothesis & \multicolumn{1}{|c|}{ Hypothesis Statement } & T-Value & Information \\
\hline $\mathrm{H}_{1}$ & Reliability has a significant effect on customer satisfaction & 1.27 & $\begin{array}{c}\text { Data does not support the } \\
\text { hypothesis }\end{array}$ \\
\hline $\mathrm{H}_{2}$ & $\begin{array}{l}\text { Responsiveness has a significant effect on customer } \\
\text { satisfaction }\end{array}$ & -0.13 & $\begin{array}{c}\text { Data does not support the } \\
\text { hypothesis }\end{array}$ \\
\hline $\mathrm{H}_{3}$ & Assurance have a significant effect on customer satisfaction & 6.30 & Data supports the hypothesis \\
\hline $\mathrm{H}_{4}$ & Reliability has a significant effect on customer loyalty & 3.88 & Data supports the hypothesis \\
\hline $\mathrm{H}_{5}$ & Responsiveness has a significant effect on customer loyalty & -1.96 & $\begin{array}{c}\text { Data does not support the } \\
\text { hypothesis }\end{array}$ \\
\hline $\mathrm{H}_{6}$ & Assurance has a significant effect on customer loyalty & -2.37 & $\begin{array}{c}\text { Data does not support the } \\
\text { hypothesis }\end{array}$ \\
\hline $\mathrm{H}_{7}$ & $\begin{array}{l}\text { Customers satisfaction has a significant effect on customer } \\
\text { loyalty }\end{array}$ & 3.67 & Data supports the hypothesis \\
\hline
\end{tabular}

Figure 1 - Path Diagram T-Value

\section{DISCUSSION OF RESULTS}

The results of testing the first hypothesis $(\mathrm{H} 1)$ found that the data supports the hypothesis with a value of $t$-value 1.27 that is reliability can affect customer satisfaction. The results of this study are in line with research conducted by Wang \& Shieh (2006) stating that overall reliability has a very positive impact on customer satisfaction. In addition, the results of this research also reinforce previous research conducted by Akhtar, et al (2011) stating that there is a positive and significant relationship between service quality and customer satisfaction such as compliance obligations, guarantees, and reliability. So, that the results of its achievement lead to satisfaction. The results of testing the second hypothesis $(\mathrm{H} 2)$ found that the data does not support the hypothesis with a t-value of 0.13 responsiveness has no relationship with customer satisfaction. The results of this research are different from previous research conducted by Guarantees and Customer Satisfaction refers to customer trust and confidence in the company to provide the best service to them (Arsanam \& Yousapronpaiboon 2014).

The results of testing the third hypothesis $(\mathrm{H} 3)$ found that the data supports the hypothesis with a t-value of 6.30 which is a guarantee that has a positive effect on customer 
satisfaction. The results of this study are in line with the research conducted by (Arsanam \& Yousapronpaiboon 2014) guarantee and customer satisfaction refers to customer trust and confidence in the company to provide the best service to customers.

The results of testing the fourth hypothesis $(\mathrm{H} 4)$ found that the data supports the hypothesis with a value of $3.88 \mathrm{t}$-value, namely reliability has a positive effect on customer loyalty. The results of this research are supported by research conducted. The findings of the study indicate that reliability has a positive relationship with customer loyalty (Kheng et al., 2010).

The results of testing the fifth hypothesis $(\mathrm{H} 5)$ found that the data did not support the hypothesis with the value of $t$-value -1.96 , namely responsiveness did not affect customer loyalty. The results of this study are in line with research conducted by (Kheng et al., 2010) that the relationship between response and customer loyalty was found to be insignificant. However, these results contradict findings that reveal a positive and significant relationship between response and loyal customers (Glaveli, Petridou, Liassides, Spathis 2006; AUKA et al., 2013).

The results of testing the first hypothesis $(\mathrm{H} 6)$ found that the data supports the hypothesis with a t-value value of -2.37 , which is a guarantee that can affect customer loyalty. Guarantees represent the knowledge and politeness of employees and their ability to inspire trust and confidence (Parasuraman et al., P. 2002) Consistent with research by Ndubisi (2006), other researchers also found a significant relationship between guarantee and customer loyalty (Lymperopoulos, Chaniotakis \& Soureli, 2006; Kheng et al., 2010; AUKA et al., 2013).

The results of the first hypothesis testing $(\mathrm{H} 7)$ found that the data supports the hypothesis with a t-value value of 3.67, namely customer satisfaction can affect customer loyalty. The results of this study are in line with research conducted by Fornell (1992) thinking that customer loyalty must be measured in two aspects: whether customers want to buy products or services consistently and whether satisfied customers are willing to pay more for products or services. Burton et al. (2003) believe that customer loyalty is determined by whether the customer's experience is satisfied. the experience of more satisfied customers, the more they are willing to buy products or services again. So that the results of its achievement lead to loyalty.

\section{MANAGERIAL IMPLICATIONS}

In maintaining the business continuity of the company, employees play an important role in maintaining business stability. In addition, within an organization, employees act as planners, implementers, supervisors and controllers of organizational activities. In this study, the company is expected to be able to further improve the quality of service in terms of reliability, responsiveness and assurance to get satisfaction and loyalty from customers. The quality of service itself greatly affects the purchasing power of customers. Service quality can also increase the value of the company and can increase the interest in purchasing power of its securities customers can increase revenue from the company.

\section{CONCLUSION}

This study aims to examine the effect of service quality on customer satisfaction and customer loyalty at PT. Multi Rentalindo. Based on the results of the research and discussion of the problem, the following conclusions were taken:

- Service quality of PT. Multi Rentalindo is included in the important category for customers. The highest service quality expected by customers is the quality of the guarantee that is equal to $6.30 \%$. The second highest service quality expected by customers is the quality of responsiveness which is equal to $3.88 \%$;

- Customer satisfaction PT. Multi Rentalindo as a whole is included in the good category which is equal to $3.67 \%$ and almost meets customer expectations for service quality. The highest customer satisfaction on guarantee quality is $6.30 \%$. PT. Multi 
Rentalindo successfully proved the quality of its guarantee to customers so that customers provide the highest rating on guarantee quality performance;

- Simultaneously, the quality of service guarantees greatly affects the customer satisfaction of PT. Multi Rentalindo is $6.30 \%$, but partially reliability and responsiveness do not affect customer satisfaction because customers need more quality assurance given by PT. Multi Rentalindo.

Some of the limitations contained in this study are: (i) This research was conducted only on employees of the company PT. Kawan Lama Group by taking the object of research at PT. Multi Rentalindo. (ii) This study only addresses the quality of service, customer satisfaction with customer loyalty. (iii) Some respondents are less serious in answering the questionnaire. (iv) Working conditions that make it difficult for some respondents to fill in questions (questionnaires).

\section{SUGGESTIONS}

By knowing that service quality variables consisting of Reliability (X1), Responsiveness (X2), and Guarantee (X3), have a significant influence on Customer Satisfaction (Y1) and Customer Loyalty (Y2), PT. Multi Rentalindo pays attention to and reconsider the importance of reliability, responsiveness and assurance in realizing an excellent service quality. In addition, some of these things will also be a benchmark for the community in choosing the services they want because along with the increase in expectations and also people's preferences to vote, it will actually trigger competition with other competitors.

- Future research is recommended to add other independent variables besides reliability, responsiveness, and assurance, which of course can affect customer satisfaction;

- Future research is recommended to study more deeply using more samples so that the research obtained can be more accurate.

For the next researcher, it is expected to be able to find other variables that support the higher value of service quality, so that in addition to the knowledge that researchers get increased, other car rental companies can consider continuing to improve services through other supporting variables, such as price factors and so forth.

\section{REFERENCES}

1. Bisnis, J. (2009). Jurnal Bisnis \& Ekonomi Studi, Vol. 15, No. 1, Musim Semi 2009, 15(1), Daniel C, N. dan Berinyuy L, P. Using The Servqual.

2. Amalia, D. (2015). Pengaruh Kualitas Pelayanan terhadap Loyalitas Pelanggan di Rental Mobil CV. Ilham Motor Gandu Mlarak Ponorogo, 1(1), 97- 114.

3. Alsarayreh, M.N. (2017). A Study of the Determinants Influencing Customer Satisfaction in the Medical Tourism Industry in Jordan, 7(3), 349-356.

4. Amalia, D. (2015). Pengaruh Kualitas Pelayanan terhadap Loyalitas Pelanggan di Rental Mobil CV. Ilham Motor Gandu Mlarak Ponorogo, 1(1), 97- 114.

5. Alsarayreh, M. N. (2017). A Study of the Determinants Influencing Customer Satisfaction in the Medical Tourism Industry in Jordan, 7(3), 349-356.

6. Alsarayreh, M.N.(2017). A Study of the Determinants Influencing Customer Satisfaction in the Medical Tourism Industry in Jordan, 7(3), 349-356.

7. Pemasaran, M. (2008). Daftar pustaka, (2007), 2006-2008.

8. Sosial, F. I., Politik, I., \& Merdeka, U. (n.d.). Pengaruh Kualitas Pelayanan Terhadap Kepuasan Dan Loyalitas Mahasiswa (Studi pada Mahasiswa

9. Strata I Fakultas IImu Sosial dan IImu Politik Universitas Merdeka Malang) Sirhan Fikri.

10. Sosial, F.I. Pengaruh Kualitas Pelayanan Terhadap Kepuasan Dan Loyalitas Mahasiswa (Studi pada Mahasiswa Strata I Fakultas IImu Sosial, IImu Politik Universitas Merdeka). 